\title{
Social Spaces Territory of Bajo Tribe's Settlement
}

\author{
Syahriana Syam ${ }^{1, *}$, Ananto Yudono ${ }^{1}$, Ria Wikantari $^{1}$, Afifah Harisah $^{1}$ \\ ${ }^{1}$ Hasanuddin University, Indonesia
}

\begin{abstract}
Kampung Bajo along the bay of Bone South Sulawesi, inhabited by Bajo tribe and Bugis tribes coexist so that there is social-cultural interaction. Since 1905 the life of the Bajo tribe has changed,they began to open themselves to relationships, initially exchange the staple for its survival. As a result of these relationships, dynamics arise in the use of space both micro space, meso and macro space in the scale of settlements, making it very difficult to see the limits of territory in the use of space. Territory deals with spaces with a certain extent where individuals or groups use and defend their exclusive territory. Seeing this, the research is important and interesting to do, focused on the concept of the territory of social space in the context of the interaction of two ethnic Bajo tribe and Bugis tribe in the form of settlement, using phenomenology method.
\end{abstract}

Keywords: Territory, Settlements, Social Space, Bajo tribe Bugis tribe

\section{Introduction}

An understanding of the cultural heritage treasures of archipelago architects is needed for practitioners of architecture for the development of creative quality. The increasing exclusion of local wisdom of archipelago architecture, encouraging the effort to save him with documentation and in-depth research. Especially local wisdom in the field of residential architecture that has a unique high value for environmental science, for the development of new theories, because it has a local space. (Sudaryono, 2003)[1]. History proves the existence of the Bajo tribe, beginning with its arrival at the coastal location, then settled and developed for generations to have the uniqueness as a marine man.

The changing environmental conditions and lifestyles of the Bajo Tribe, according to Rapoport (1969)[2] that change is the result of the process of adjustment activity carried out by man himself so that his needs can be fulfilled. . The change of the sea into the settlement of Kampung Bajo has an impact on the change of building form which produces social space as a container of interaction. Lefebvre (1991: 26)[3] that the social space of a social product, which is a specific representation of the social interaction between production and reproduction. The perception of space between them can be clarified with territory to know the limits of mastery of space clearly.

Altaman and Chemers (1984: 121)[4] territory is the control over the use of a place or object, the control of an unauthorized person or the use of others who are permitted to a limited extent. Territory concept defined as a spatial and physical boundary or marker is primarily the possibility of other party intervention, so that each group has a different expression in the phenomenon of territory and its privacy. The concept of territory of social space in the context of the interaction of the two ethnic Bajo tribes and the Bugis tribe in the form of settlement, is, a comprehensive study of the social aspects of settlements that will study the formation of territory, which will enrich the concept of territory in the treasury of architectural theory.

This research uses the phenomenology paradigm, which an empirical study that investigates social phenomena in the context of settlements in Bajo with locus in Kampung Bajo, Bone regency of South Sulawesi. The result of this research is to find out the concept of social space territory that is formed and show the development of architectural theory about the concept of territory in Bajo tribe settlement formed by social aspect (interaction, behavior, social structure of society) and culture.

\section{Characteristics of Bajo Tribal Settlements}

Rossi (1982: 59) explains that the components of settlements include roads, open spaces and types of buildings that involve physical elements of nature and non-physical (human) both individually and community groups along with all life activities, then Rossi explained that the neighborhood is a combination between footprint, event and sign (sign). Therefore, the settlement environment indicates the existence of physical and non-physical impact on the site which as a whole is a sign of a certain event, so that it can be characteristic of a settlement environment.

The elements of nature, environment, culture and residence are a unity, in which the natural environment shapes the culture of society, and culture is manifested through the shelter formed by the condition of the natural environment. The element of the natural 
environment is the most important element and can affect other elements, where the natural environment has territorial boundaries in nature. So that characteristics can be obtained from the physical condition of the environment, culture and social life related to the history of society through space and time.

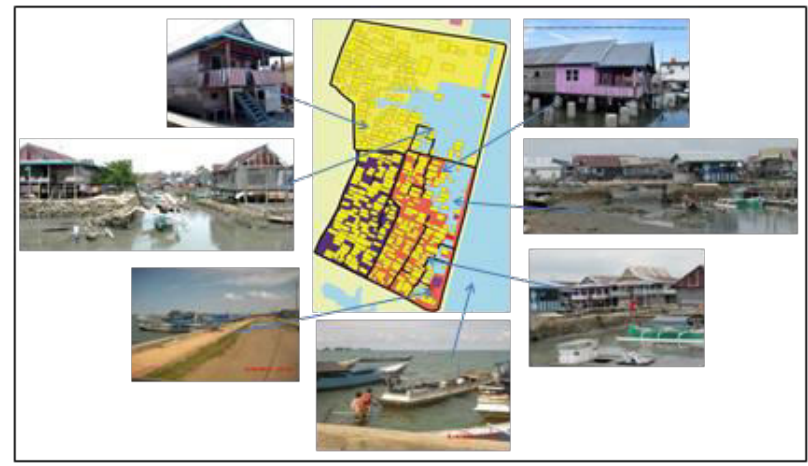

Fig. 1. Research Sites of Bajo Settlements of Tanete Riattang Timur Subdistrict of Bone District of South Sulawesi.

Figure 1. Provides an overview of Kampung Bajo neighborhood in Teneteriattang Timur District of Bone District. Characteristics and uniqueness of the Bajo Tribe as a study area, geographically, located along the coast of Bone Bay, and the sea as its main orientation. The history of the existence of fishermen settlements began from the arrival of a group of ethnic Bajo tribes in the waters of Bone Bay, living in groups on the boat, then develop from generation to generation coexist with Bugis tribe.

The settlement areas on water from boats to houses on stilts, dominated by fishing settlements, are built with their local knowledge that is influenced by geographical conditions, sea orientation. Furthermore, the building developed into three zones, namely; buildings on the water, between water-land, and on land.

\section{Social Space of Bajo Tribal Settlements}

Some traditional Indonesian settlements originating from locality, meaning macro-micro cosmos, functional and socially symbolic meaning can be seen from beliefs, customs, traditions. rituals to form relations between residence and environment according to the cultural characteristics of the community. They will depend on the condition of the natural environment, as does the Bajo Tribe with the sea.

Rapoport (2005: 24)[5], that the environment can be understood as organization of space, organization of time, meaning, communication or interaction, Rapoport (2005: 32)[5], there are three elements forming a setting that is, fixed element in the form of infrastucture, remains surrounded by delimiters that are relatively fixed and not easily shifted. Semi fixed element, in the form of furniture and all the completeness of the environment either inside or outside the environment, can move. Non-fixed elements of human form and existing activities, behavior, clothes, hair shape, animal, or animal. Existing properties emphasize the functionality and users of the space components. The hierarchy of space formed in the settlements of the Bajo tribe, oriented towards the direction of the growth of settlements from the sea to the mainland. Sequentially, increasingly toward the sea (water zone) inhabited by Bajo tribe, and towards the mainland inhabited by Bugis tribe, but facilities and infrastructure are shared, peaceful coexistence. In table 1, explains some of the interaction spaces used by Bajo villagers

Table 1. Elements of the Social Space of Bajo Tribal Settlements.

\begin{tabular}{|c|c|c|c|}
\hline \multicolumn{4}{|c|}{ Elements of Social Interaction Space } \\
\hline $\begin{array}{l}\text { Public } \\
\text { Space } \\
\text { Area }\end{array}$ & $\begin{array}{l}\text { Favorite } \\
\text { Places }\end{array}$ & $\begin{array}{l}\text { Territory } \\
\text { Symbol }\end{array}$ & Activities \\
\hline \multirow[t]{9}{*}{$\begin{array}{ll}\text { On } & \text { The } \\
\text { Land } & \end{array}$} & $\begin{array}{l}\text { Environment } \\
\text { Street }\end{array}$ & Non-fix & $\begin{array}{l}\text { Gathering, } \\
\text { Chat, } \\
\text { Playing, and } \\
\text { Parking } \\
\text { Place }\end{array}$ \\
\hline & Footpath & $\begin{array}{l}\text { Non-fix } \\
\text { Flower pot, } \\
\text { clothesline }\end{array}$ & $\begin{array}{l}\text { Sitting and } \\
\text { Chat }\end{array}$ \\
\hline & $\begin{array}{l}\text { House Front } \\
\text { Yard }\end{array}$ & Non-fix & $\begin{array}{l}\text { Sitting, } \\
\text { Gathering, } \\
\text { and Chat. }\end{array}$ \\
\hline & Stairs & Non-fix & $\begin{array}{l}\text { Sitting, Chat, } \\
\text { look for fleas } \\
\text { on each } \\
\text { other. }\end{array}$ \\
\hline & Lego-lego & $\begin{array}{l}\text { Non-fix } \\
\text { Table } \\
\text { chairs }\end{array}$ & $\begin{array}{l}\text { Sitting, } \\
\text { Gathering, } \\
\text { and Chat. }\end{array}$ \\
\hline & Stall & Non-fix & $\begin{array}{l}\text { Gathering, } \\
\text { Buying and } \\
\text { Selling } \\
\text { Activity. }\end{array}$ \\
\hline & Workshop & $\begin{array}{l}\text { Non-fix } \\
\text { Cupboard }\end{array}$ & $\begin{array}{l}\text { Sitting, } \\
\text { Motor and } \\
\text { Bike Service. }\end{array}$ \\
\hline & Empty Land & $\begin{array}{lr}\text { Semi } & \text { fix } \\
\text { a pile of } \\
\text { stones, } \\
\text { sand, } \\
\text { animals }\end{array}$ & $\begin{array}{l}\text { Drying Seas } \\
\text { Product, Sea } \\
\text { weed, and } \\
\text { Play ground } \\
\text { for kid. }\end{array}$ \\
\hline & $\begin{array}{ll}\text { Under } & \text { The } \\
\text { House } & \end{array}$ & $\begin{array}{l}\text { Fix Column } \\
\text { house, wall }\end{array}$ & $\begin{array}{l}\text { Food Stall, } \\
\text { Cooking, } \\
\text { Resting, } \\
\text { Eating, and } \\
\text { Gathering. }\end{array}$ \\
\hline \multirow[t]{4}{*}{$\begin{array}{l}\text { Transition } \\
\text { Water - } \\
\text { Land }\end{array}$} & Tetean & $\begin{array}{l}\text { Fix } \\
\text { bamboo, } \\
\text { wood }\end{array}$ & $\begin{array}{l}\text { Acces for a } \\
\text { residential } \\
\text { above the } \\
\text { water, sitting } \\
\text { and playing } \\
\text { for kid. }\end{array}$ \\
\hline & Levee & $\begin{array}{l}\text { Fix streets, } \\
\text { stone walls }\end{array}$ & $\begin{array}{l}\text { Sitting, } \\
\text { Rilexing, } \\
\text { Playing, and } \\
\text { Eating. }\end{array}$ \\
\hline & Bridge & Fix & $\begin{array}{l}\text { Gathering } \\
\text { and Playing. }\end{array}$ \\
\hline & Dock & Fix & $\begin{array}{l}\text { Boot } \\
\text { Mooring, } \\
\text { Gathering }\end{array}$ \\
\hline
\end{tabular}




\begin{tabular}{|l|l|l|l|}
\hline & $\begin{array}{l}\text { a Mound of } \\
\text { rocks above } \\
\text { the sea }\end{array}$ & Fix & $\begin{array}{l}\text { Sitting and } \\
\text { Fishing. }\end{array}$ \\
\cline { 2 - 4 } & Lopi-lopi & Semi-fix & $\begin{array}{l}\text { Sitting, } \\
\text { Gathering, } \\
\text { and Resting. }\end{array}$ \\
\hline
\end{tabular}

The house is located on the water (based on the tide of sea water, that the position between one row (saf) with another row in the house there are boat streets, and akse directly into the open sea through the culvert under the bridge, so that each boat can be moored next to their homes.

To connect one house with another house on the water, made tetean from bamboo or wooden planks. While the existing house on land use paving block as a hardening for access path. The layout of the buildings lined up along the coast, each with access to water. With the agreement of the people and on the basis of mutual assistance, the pile of rocks is made as breakwaters in the event of high tide. In addition, the stone tumbukn also serves as the boundary of their land plot, so that the land is also used as an area where tether their lopi-boat (small boat) at the time of berthing (not down to the sea).

Table 2. Periodization of Bajo Tribal Settlement Environment.

\begin{tabular}{|c|c|c|c|c|c|c|c|c|}
\hline Dev. Period & $\begin{array}{l}\text { Up to } \\
1800 s\end{array}$ & 1850s & 1900s & 1920s & 1950s & 1970s & 1980s & 1990s-at present \\
\hline Location & Cellu & Bajoe & Lassareng & Lassareng & Lassareng & Bajoe & Bajoe & Bajoe \\
\hline \multirow[t]{7}{*}{ Way of living } & Nomadic & Nomadic & Nomadic & $\begin{array}{l}\text { Semi- } \\
\text { settled }\end{array}$ & $\begin{array}{l}\text { Semi- } \\
\text { Settled }\end{array}$ & Settled & Settled & Settled \\
\hline & $\begin{array}{l}\text { On-sea } \\
\text { water }\end{array}$ & $\begin{array}{l}\text { On-sea } \\
\text { water }\end{array}$ & $\begin{array}{l}\text { On-sea } \\
\text { water }\end{array}$ & $\begin{array}{l}\text { On-sea } \\
\text { water }\end{array}$ & $\begin{array}{l}\text { On-sea } \\
\text { water }\end{array}$ & On-sea water & On-sea water & $\begin{array}{l}\text { Coastal water } \\
\text { (intertidal) }\end{array}$ \\
\hline & & & & $\begin{array}{l}\text { Coastal } \\
\text { water } \\
\text { (intertidal) }\end{array}$ & $\begin{array}{l}\text { Coastal } \\
\text { water } \\
\text { (intertidal) }\end{array}$ & $\begin{array}{l}\text { Coastal water } \\
\text { (intertidal) }\end{array}$ & $\begin{array}{l}\text { Coastal water } \\
\text { on-land }\end{array}$ & $\begin{array}{l}\text { On-land } \\
\text { On-sea water }\end{array}$ \\
\hline & \multirow[t]{2}{*}{ Cluster } & \multirow[t]{2}{*}{ Cluster } & \multirow[t]{2}{*}{ Cluster } & \multirow[t]{2}{*}{ Linear rows } & \multirow[t]{2}{*}{ Linear rows } & \multirow[t]{2}{*}{ Linear rows } & \multirow[t]{2}{*}{ Linear rows } & Linear rows \\
\hline & & & & & & & & Cluster \\
\hline & \multirow[t]{2}{*}{ Seafaring } & \multirow[t]{2}{*}{ Seafaring } & \multirow[t]{2}{*}{ Seafaring } & \multirow[t]{2}{*}{ Seafaring } & \multirow[t]{2}{*}{ Seafaring } & \multirow[t]{2}{*}{ Seafaring } & \multirow[t]{2}{*}{ Seafaring } & Seafaring \\
\hline & & & & & & & & Others \\
\hline \multirow[t]{2}{*}{$\begin{array}{l}\text { Type of } \\
\text { dwelling }\end{array}$} & \multirow[t]{2}{*}{$\begin{array}{l}\text { Boat } \\
\text { (bidok) }\end{array}$} & \multirow[t]{2}{*}{$\begin{array}{l}\text { Boat } \\
\text { (bidok) }\end{array}$} & \multirow[t]{2}{*}{ Boat (bidok) } & \multirow[t]{2}{*}{$\begin{array}{l}\text { Temporary } \\
\text { shelter } \\
\text { (Babaroh) }\end{array}$} & $\begin{array}{l}\text { Temporarys } \\
\text { helter } \\
\text { (Babaroh) }\end{array}$ & $\begin{array}{l}\text { Semi- } \\
\text { permanen } \\
\text { shelter } \\
\text { (papondok) }\end{array}$ & $\begin{array}{l}\text { Semi-permanen } \\
\text { shelter } \\
\text { (papondok) }\end{array}$ & \multirow[t]{2}{*}{$\begin{array}{l}\text { Permanent house } \\
\text { (rumak) }\end{array}$} \\
\hline & & & & & $\begin{array}{l}\text { Semi- } \\
\text { permanent } \\
\text { shelter } \\
\text { (papondok) }\end{array}$ & $\begin{array}{l}\text { Permanent } \\
\text { house (rumak) }\end{array}$ & $\begin{array}{l}\text { Permanent } \\
\text { house (rumak) }\end{array}$ & \\
\hline $\begin{array}{l}\text { Territory } \\
\text { symbol }\end{array}$ & \multicolumn{4}{|c|}{ Taguk Pulih Connection } & \multicolumn{3}{|c|}{ Taguk Pulih dan Tetean Connection } & $\begin{array}{l}\text { Connection } \\
\text { tetean / road, } \\
\text { bridge tetean / } \\
\text { road, bridge } \\
\text { /tetean / road, } \\
\text { bridge }\end{array}$ \\
\hline
\end{tabular}

Bajo tribal settlements begin when they feel safe to settle in groups living on a boat (boat) consisting of 1520 families in the bone bay. Each house is declared as one household although there are more than one family in it. The composition of his house was built in such a way, in accordance with their philosophy patepik-tepik dipadijer (gathering, lined and blessed).
According to Table 2, the history of the changes that took place in the Bajo tribal settlements began with the nomadic life of Lassareng Island, a coral island far from the mainland, and eventually settled in Kampung Bajo and lived side by side with the Bugis. As they live in the sea, spatial batters are used as markers of territory, their kampung habits. Around 1970, the Bajo tribe began to settle and built a stage house (papondok), then in 1980 became a permanent home, in 1990 until today settlement land on water and on land based on tides.

Although in general the orientation of the tribe of Bajo houses faces the sea (east), but in fact found a house on the land there is facing the road. By reason of respect for the road. In their efforts to keep the belief that their home should face the sea as a tribute to the sea that is considered their only source of life, they also create a special door that opens directly toward the sea, so the back of the sea is not firmly apparent.

The seven zoning spaces in the picture above in figure 2, can be found at the house of the tribe of Bajo. The first zone, an outer space consisting of awa ball, addeneng (take home, and ladder elements), which functioned as access to territory on the outside of the house without waiting for permission from homeowners. The agreement was understood by the whole Bajo tribal community, and formed temporal territory. But in this study, is focusing on the space of social interaction, resulting in social territory.

Users in the Bajo home tribe's settings are five household heads, tagga housewives, family members, relatives, neighbors / guests. This can illustrate how the relationship and complexity of activities that take place within the house. Activities that are in the house and related to the sea merupan adaptation of zonation results that form social territory on Bajo tribal settlements. 


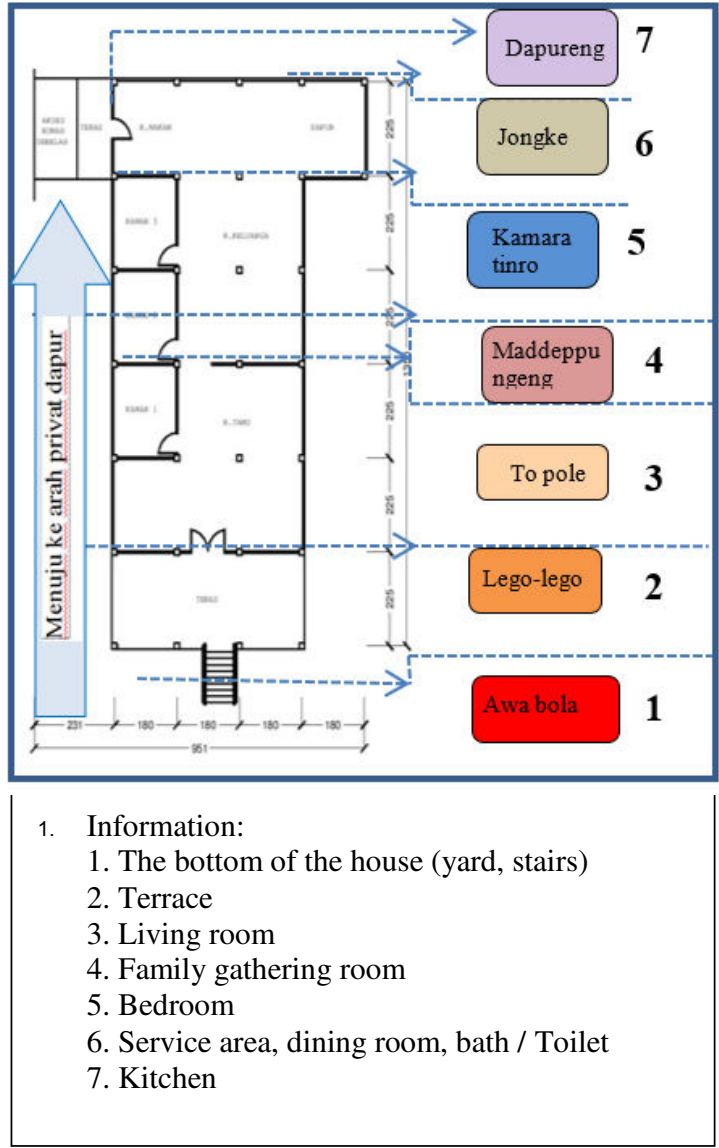

Fig. 2. Hierarchy home space Suku Bajo.

Of the seven zonations, the lego-lego section is an area that is considered to have an important role in the social interaction activities of the community. The territory of the lego-lego room is accessible to all family members and guests. Various activities that exist in this place, such as a place to gather, sit, rest, a place to store the seafood such as fish, drying places, stalls or selling. Someone who comes to visit or visit, homeowners can give access to enter the territory topole (living room).

Overall, social space of the Bajo tribal settlements can be categorized into two zones ie on land and between water-land, favorite locations such as (sea, roads, bridges, tetes, lego-lego or the front of the house) . In this space the activities of trade, social, gathering, rest and have created a strong emotional bond between citizens, thus obscuring the territory of space.

\section{Conclusion}

Territory formed in Bajo settlement is inseparable from historical values, natural environment condition, sea as main orientation and privacy demand in the form of motivation of economic interest. Territory categories that have been unique to the uniqueness, social aspects and similarities of marine and economic cultural backgrounds can foster a strong sense of kinship, thus eliminating the boundaries of space and time in their daily interactions and activities. Bajo tribal people enjoy doing private activities together, with awareness or unintentionally intervene in the privacy space by passing the territorial boundaries.

\section{References}

Altman.I, Chemens, M 1984. Culture and Environment, Brooks/Cole Publishing Company Monterey, California.

Lefebvre, Henry (1991), The Production of Space, Blackwell Oxford, UK \& Cambridge, USA

Lowe, 2003, The Magic of Place: Same at Sea and on Land in Sulawesi, Indonesia, in Bijdragen tot de Taal, Land-en Volkenkunde, 2003, Leiden, http: www.kitly-journls.nl

Mulyati, Ahda, Sama in Lao as the Foundation for the Establishment of Bajo Tribal Architecture in Central Sulawesi's Kabalutan Island, Dissertation, PPS of Gadah Mada University Yogyakarta.

Purbadi, YD, 2010, Tribal and Spatial Arrangements on Dawan Tribal Settlement Architecture in Kaenbaun Village on Timor Island, Dissertation, PPS Universitas Gadah Mada Yogyakarta.

Rapoport,A, 2005, Culture Architecture and Design, Locke Science publishing Company, Inc, Chicago, Illinois,USA.

Said, Ratriana, 2016, Diversity and Utilization of Public Space in RusunawaMariso, Makassra-Indonesia Jurnal JAABE.

Syam, Syahriana, 2016, Community Attachment to Public Space Vernaculer on Ethnic Settlement, The 10th International Symposium on City Planning, Makassar Indonesia. 